\title{
COX-2 gene expression in colon cancer tissue related to regulating factors and promoter methylation status
}

\author{
Annika Gustafsson Asting ${ }^{1}$, Helena Carén², Marianne Andersson', Christina Lönnroth ${ }^{1}$, Kristina Lagerstedt $^{1}$ \\ and Kent Lundholm ${ }^{1 *}$
}

\begin{abstract}
Background: Increased cyclooxygenase activity promotes progression of colorectal cancer, but the mechanisms behind COX-2 induction remain elusive. This study was therefore aimed to define external cell signaling and transcription factors relating to high COX-2 expression in colon cancer tissue.

Method: Tumor and normal colon tissue were collected at primary curative operation in 48 unselected patients. COX-2 expression in tumor and normal colon tissue was quantified including microarray analyses on tumor mRNA accounting for high and low tumor COX-2 expression. Cross hybridization was performed between tumor and normal colon tissue. Methylation status of up-stream COX-2 promoter region was evaluated.

Results: Tumors with high COX-2 expression displayed large differences in gene expression compared to normal colon. Numerous genes with altered expression appeared in tumors of high COX-2 expression compared to tumors of low COX-2. COX-2 expression in normal colon was increased in patients with tumors of high COX-2 compared to normal colon from patients with tumors of low COX-2. IL1 $\beta$, IL6 and iNOS transcripts were up-regulated among external cell signaling factors; nine transcription factors (ATF3, C/EBP, c-Fos, Fos-B, JDP2, JunB, c-Maf, NF- $\kappa$ B, TCF4) showed increased expression and 5 (AP-2, CBP, Elk-1, p53, PEA3) were decreased in tumors with high COX-2. The promoter region of COX-2 gene did not show consistent methylation in tumor or normal colon tissue.
\end{abstract}

Conclusions: Transcription and external cell signaling factors are altered as covariates to COX-2 expression in colon cancer tissue, but DNA methylation of the COX-2 promoter region was not a significant factor behind COX-2 expression in tumor and normal colon tissue.

\section{Background}

Colorectal cancer is common in Western countries with unanimous findings that prostaglandins are important for both carcinogenesis and progression [1-3]. It has been repeatedly observed that Cyclooxygenase-1/-2 inhibition attenuates appearance of epithelial cancer in experimental models and in part also in patients. Both primary and secondary prevention with cyclooxygenase (COX) inhibitors demonstrate and confirm decreased incidence of colorectal carcinoma in both retrospective and randomized patient cohorts [4-7]. Thus, a large

\footnotetext{
* Correspondence: Kent.lundholm@surgery.gu.se

'Department of Surgery, Institute of Clinical Sciences, Sahlgrenska Academy,

Sahlgrenska University Hospital, Gothenburg, Sweden

Full list of author information is available at the end of the article
}

number of observations emphasize that induced prostaglandin production, particularly $\mathrm{PGE}_{2}$, is involved in cell signaling through prostanoid receptors, where our own observations suggested subtype $\mathrm{EP}_{2}$ receptor expression in colon cancer tissue to predict reduced survival [2]. An important issue behind the appearance and progression of colorectal cancer seems to be increased production of $\mathrm{PGE}_{2}$ secondary to COX-2 induction in both transformed epithelial cells and host stroma [2,4,8-11]. Mechanisms behind COX-2 gene induction in colorectal cancer disease remain elusive, although a lot of information is available on the regulation of COX-2 gene expression [12,13]. Most such information has, however, been obtained in isolated cell culture experiments with obvious limitations compared to the in vivo situation

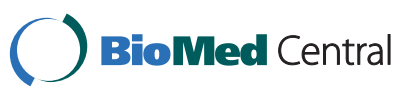

() 2011 Asting et al; licensee BioMed Central Ltd. This is an Open Access article distributed under the terms of the Creative Commons Attribution License (http://creativecommons.org/licenses/by/2.0), which permits unrestricted use, distribution, and reproduction in any medium, provided the original work is properly cited. 
based on uninterrupted host and tumor cell signaling. Therefore, the aim of the present study was to relate well-recognized external cell- and transcription factor expression to elevated tumor COX-2 expression in colorectal cancer tissue at primary operations aimed at cure.

\section{Methods \\ Patients}

Tumor and colon tissue samples were collected from 48 unselected patients at primary operation for colorectal carcinoma between 2001 to 2004 in Uddevalla county of Sweden. All patients underwent surgery as the only curative treatment and none received neoadjuvant radio-chemotherapy, according to individual decisions and institutional indications. Normal colon tissue was collected as a minimum of $10 \mathrm{~cm}$ away from the macroscopically seen tumor tissue. The group of patients consisted of 54\% males and 46\% females with a mean age of 72.5 years (range 40 to 91 years) at surgery. Mean survival time was $27.3 \pm 4.2$ months (range 0 to 73 months) following surgery according to a recent update of survival (Dec 2008), where 21 patients were still alive. Tumors were histologically classified as Dukes A (8), Dukes B (19), Dukes C (11) and Dukes D (10). PCR analysis was performed to quantify COX-2 mRNA expression [2]. Mean COX2 expression in tumor tissue for the entire group was $6.27 \pm 0.60 \mathrm{~mol} / \mathrm{mol} \mathrm{GAPDH}$ (range 0.11 to 24.67 ) (n $=48)$ and $14.6 \pm 1.7$ (range 1.7 to 38.08$)(\mathrm{n}=29)$ in normal colon tissue. Patients used in subsequent experiments were selected according to COX-2 expression in tumors; one group of 10 patients with highest and one group of 10 patients with lowest COX-2 expression (Figure 1, Table 1).

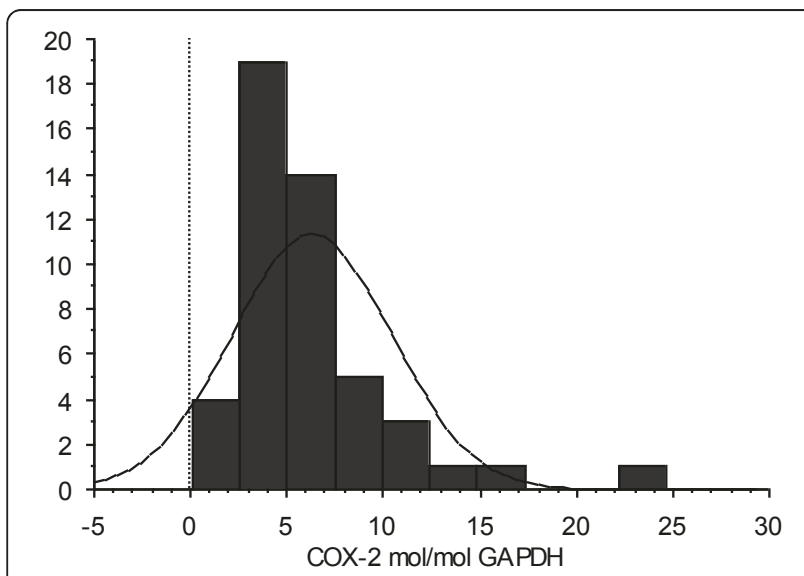

Figure 1 Distribution of COX-2 among patients ( $n=48$ ). COX-2 expressions of tumors used in this study were distributed at the top and bottom quartile.
Table 1 Classification of patients with high or low COX-2 expression in tumor tissue

\begin{tabular}{lcc}
\hline & \multicolumn{2}{c}{ COX-2 expression in tumor tissue } \\
\hline & High (10) & Low (10) \\
\hline COX-2 T & $12.5 \pm 1.5$ & $2.6 \pm 0.4$ \\
(mol/mol GAPDH) NM & $5.06 \pm 3.0$ & $12.3 \pm 4.0$ \\
\hline Dukes $^{1}$ & $3 \mathrm{~A}, 6 \mathrm{~B}, 1 \mathrm{D}$ & $3 \mathrm{~B}, 5 \mathrm{C}, 2 \mathrm{D}$ \\
\hline Age at surgery & $71 \pm 2.5$ & $73 \pm 3.4$ \\
\hline Gender & $6 \mathrm{M}, 4 \mathrm{~F}$ & $4 \mathrm{M}, 6 \mathrm{~F}$ \\
\hline Postoperative survival (months) & $23 \pm 5.8$ & $29 \pm 8.0$ \\
\hline Right/left colon & $4 / 6$ & $4 / 6$
\end{tabular}

Mean \pm SEM.

$\mathrm{T}=$ tumor tissue.

$\mathrm{NM}=$ Normal colon tissue

${ }^{1}$ Approx. TNM; A = T1, N0, M0; B = T2/T3, N0, M0; C = T2/T3/T4, N1/N2, M0;

$\mathrm{D}=\mathrm{T} 2 / \mathrm{T} 3 / \mathrm{T} 4, \mathrm{~N} 1 / \mathrm{N} 2, \mathrm{M} 1$

\section{RNA and DNA extraction}

Tumor and normal colon tissue samples were collected down to the serosa layer during surgery and kept fresh frozen in liquid nitrogen and stored in $-80^{\circ} \mathrm{C}$ until analysis. Certified pathologists staged all tumors. Tumor samples were secured by the surgeon in charge and contained around $55-75 \%$ tumor cells according to random visual inspection. RNA extraction and cDNA synthesis were performed as described [2]. A quality check of RNA in all samples was done in Bioanalyzer 2100 with limit RIN 6.0 for further analysis (Agilent). DNA was extracted with QIAamp ${ }^{\circledR}$ DNA Mini Kit (Qiagen) according to instructions. RNase A solution (Promega) was used as extra step in DNA purification. Concentration of RNA and DNA was determined in NanoDrop ${ }^{\circledR}$ ND-1000 Spectrophotometer (NanoDrop Technologies).

\section{Gene expression analysis}

Microarray analysis was performed on pooled tumor mRNA from 9 out of 10 patients with high COX-2 mRNA expression versus 9 out of 10 patients with low COX-2 mRNA expression. The two patients were excluded due to low RIN indicating poor RNA quality. $500 \mathrm{ng}$ of mRNA from tumors with high COX-2 patients was labeled with Cy-3-dCTP (Amersham BioSciences) in a cDNA synthesis reaction with Agilent Flourescent Direct Label. Tumor samples with low COX-2 expression (500 ng) were labeled with Cy-5dCTP. Pooled tumor cDNA from patients with high COX-2 versus pooled DNA from patients with low COX-2 expression were then hybridized on whole human oligo genome microarrays $(4 \times 44 \mathrm{~K}$ expression arrays, Agilent) during $18 \mathrm{hrs}$ followed by post-hybridization washes according to in situ instructions (Hybridization Kit Plus, Agilent). Microarrays were quantified on 
Agilent G2565 AA microarray scanner and data were pre-processed in Feature Extraction 9.1 software program (Agilent). The same procedures were performed with normal colon mucosa tissue from all patients with only 4 patients per pool due to poor RNA quality. One hybridization with high COX-2 tumor expression versus corresponding normal colon mucosa tissue was also performed. Four technical replicates of all tumor tissue analyses and two technical replicates of normal colon tissue and tumor versus normal colon tissue analyses were performed. Dye-normalized, outlier- and background subtracted values were analyzed in GeneSpring GX 10 software program (Agilent) according to standard procedures. A quality control was performed with QC metrics. Analysis used were filter on flags (present or marginal) were 27194 probes (out of 41078) passed in 2 out of 4 technical replicates with tumor tissue. In normal tissue 25735 probes passed and in tumor vs normal tissue 27919 probes passed filter on flags for further analysis with t-test $(\mathrm{p}<0.05)$. Fold change 1.5 of $\log 2$ transformed ratios was considered a statistically significant change in gene expression. Significant pathway analysis with entity list FC 1.5 was used to define significantly altered pathways. PCR analyses were performed at Tataa Biocenter (Gothenburg, Sweden) in a LightCycler 480 Probe Master (Roche). PCR assays (AKT1 HS00178289_m1, IL1B HS01555410_m1, IL6 HS00985639_m1, TRA@ HS 00612292_m1, CARD11 HS01060626_m1, Applied Biosystems) were tested and validated for efficiency and specificity. All samples were run in duplicate and negative controls were negative. Results were related to assay efficiency and GAPDH (GAPDH assay from Tataa Biocenter's Reference Gene Panel Human) and calculated according to comparative $\mathrm{Ct}$ method.

\section{DNA methylation analysis with bisulfite sequencing}

Methylation analysis was performed with tag-modified bisulfite genomic sequencing [14]. EpiTect ${ }^{\mathbb{B}}$ Bisulfite kit (Qiagen) was used for bisulphite modification of $1 \mu \mathrm{g}$ tumor and normal colon tissue DNA from each patient $(\mathrm{n}=20)$ according to instructions. Modified DNA samples were amplified with two different sets of primers (Table 2) directed towards two areas of the COX-2 promoter region using touchdown PCR $(1 \times$ Reaction Buffer, $0.5 \mathrm{mM}$ dNTPs, $2.0 \mathrm{mM} \mathrm{MgCl} 2,0.4 \mu \mathrm{M}$ forward and reverse primers resp., and 1 unit HotStart Taq (Qiagen).
Primer pair 1 was taken from Hur et al. and primer pair 2 was designed with BiSearch $[15,16]$. PCR reactions were denatured at $95^{\circ} \mathrm{C}$ for $10 \mathrm{~min}$, then 20 cycles of $95^{\circ}$ $\mathrm{C} 45 \mathrm{~s}, 60^{\circ} \mathrm{C} / 65^{\circ} \mathrm{C}$ annealing temperature with a decrease of half a degree per cycle for $45 \mathrm{~s}, 68^{\circ} \mathrm{C} 60 \mathrm{~s}$ followed by $15-20$ cycles of $95^{\circ} \mathrm{C} 45 \mathrm{~s}, 50^{\circ} \mathrm{C} / 55^{\circ} \mathrm{C} 45 \mathrm{~s}$ and $68^{\circ} \mathrm{C} 60 \mathrm{~s}$ ended with a $7 \mathrm{~min}$ extension at $68^{\circ} \mathrm{C}$. EpiTect ${ }^{\circledR} \mathrm{PCR}$ Controls (Qiagen) was used to ensure that the reaction worked properly; one methylated control sample, one unmethylated control and a 50/50 mixture of methylated and unmethylated controls were included in each PCR to ensure that methylated and unmethylated template were both equally amplified. The specificity of PCR products was inspected by use of 2100 Bioanalyzer according to protocol for DNA 1000 (Agilent). PCR products were then purified using Agencourt AMPure magnetic beads (Agencourt Bioscience Corporation) using the Biomek NX pipetting robot (Beckman Coulter) and eluted in distilled water. Sequence PCR was performed using forward or reverse primer with the ABI Prism BigDye ${ }^{\mathrm{TM}}$ cycle sequencing Ready Reaction Kit v1.1 (Applied Biosystems). Sequence PCR was run in $10 \mu$ reactions under following conditions: $96^{\circ} \mathrm{C} 1 \mathrm{~min}$, followed by 25 cycles of $96^{\circ} \mathrm{C} 10 \mathrm{~s}$ and $50^{\circ} \mathrm{C} 4 \mathrm{~min}$. Sequencing products were purified using CleanSeq magnetic beads (Agencourt) using the Biomek NX and re-suspended in $10 \mu \mathrm{l}$ of High Dye formamide (Applied Biosystems). The sequencing products were separated with gel electrophoresis on a 3730 DNA analyser (Applied Biosystems) and the output data were viewed and analysed using Sequence Analysis v5.2 (Applied Biosystems) and BiqAnalyzer [17].

\section{Statistics}

Results are presented as mean \pm SEM. Statistical analyses were performed by ANOVA and $p<0.05$ was regarded significant in two-tailed tests. This study was approved by the board of Ethics at University of Gothenburg (NCT00473980). Accordingly, all patients participated with informed consent.

\section{Results}

\section{COX-2 expression}

Large difference in gene expression was observed when comparing tumor tissue with high COX-2 expression to normal colon mucosa tissue from the same patients $(2557 \uparrow, 3182 \downarrow)$ (Table 3). A large number of genes with

Table 2 Primers used for methylation analysis

\begin{tabular}{llll}
\hline & Tag & Primer Sequence $\left(\mathbf{5}^{\prime} \mathbf{}^{\prime} \mathbf{3}^{\prime}\right)$ & Bp \\
\hline 1 & FP1692 & CCACTCACTCACCCACCCGAAGAAGAAAAGATATTTGG & 448 \\
\hline 2 & RP2104 & GGGTGGGAGGTGGGAGGGATAAACTTTACTATCTAAAA & \\
\hline 2 & B1(1595) & CCACTCACTCACCCACCCTTGGAGAGGAAGTTAAGTGTT & 223 \\
\hline
\end{tabular}


altered expression appeared also in colon cancer tissue of tumors with high COX-2 expression when compared to tumors with low COX-2 expression $(3086 \uparrow, 3031 \downarrow)$ (Table 4). Expression of COX-2 in normal colon mucosa tissue was significantly increased in patients with tumors of high COX-2 expression compared with mucosa from

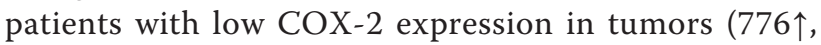
$804 \downarrow)$. Highly expressed genes in tumor tissue with high COX-2 expression were associated to cell motility, cell structure, muscle proteins, and energy homeostasis while down-regulated genes in such tumors seemed to be related to tumor antigens as Melanoma antigen and Chondrosarcoma ass. Gene, etc (Table 4). Several factors of immune response as serpin peptidase inhibitor and inducible metric oxide synthase 2 with antitumoral activities were either up- or down-regulated in normal colon tissue from patients with tumors of high COX-2 expression (Table 5). Patients with tumors with high
COX-2 expression did not in the present material display significantly reduced survival compared to patients with tumors with low COX-2 expression (Table 1). However, COX-2 expression predicted survival at borderline significance in a larger patient material [2].

\section{Transcription factors}

A large number of transcription factors with reported importance for regulation of the COX-2 gene in human cells were evaluated and are listed in Table 6. Eight of these transcription factors showed increased expression, while 5 transcription factors were down-regulated in tumors with high COX-2 expression.

\section{External factors}

Genes with reported functions in external cell signaling indicated 6 genes with increased expression, while no gene indicated down-regulation related to high COX-2

Table 3 Genes listed according to the magnitude of most altered expression between tumor tissue and normal mucosa from the same patients with tumors of high intrinsic COX-2 expression

\begin{tabular}{|c|c|c|c|c|}
\hline Gene & $\uparrow / \downarrow$ & FC & Function & $\begin{array}{l}\text { Gene Symbol } \\
\text { (GenelD) }\end{array}$ \\
\hline Matrix metallopeptidase 7 & $\uparrow$ & 110 & Breakdown of extracellular matrix, metastasis & MMP7 (4316) \\
\hline Keratin 23 & $\uparrow$ & 77 & Structural integrity of epithelial cells & KRT23 (25984) \\
\hline Myosin & $\uparrow$ & 63 & Muscle, heavy polypeptide 2 & MYH2 (4620) \\
\hline Claudin 1 & $\uparrow$ & 38 & Integral membrane protein, component of tight junction strands & CLDN1 (9076) \\
\hline Actin $\alpha 1$, skeletal & $\uparrow$ & 36 & Cell motility, structure and integrity & ACTA1 (58) \\
\hline Forkhead box Q1 & $\uparrow$ & 34 & Transcription factor (i.e. TGF-beta2) & FOXQ1 (94234) \\
\hline $\begin{array}{l}\text { Proprotein convertase subtilisin/ } \\
\text { kexin type } 1\end{array}$ & $\uparrow$ & 22 & $\begin{array}{l}\text { Regulating insulin biosynthesis, obesity, activate precursor protein, associated with } \\
\text { carcinoid tumors }\end{array}$ & PCSK1 (5122) \\
\hline Sarcolipin & $\uparrow$ & 25 & Regulates several sarcoplasmic reticulum $\mathrm{Ca}(2+)$-ATPases & SLN (6588) \\
\hline Matrix metallopeptidase 1 & $\uparrow$ & 14 & Breakdown of extracellular matrix, metastasis & MMP1 (4312) \\
\hline Myosin, cardiac, beta & $\uparrow$ & 25 & $\begin{array}{l}\text { Heavy chain, also expressed in skeletal muscle tissues rich in slow-twitch type I } \\
\text { muscle fibers }\end{array}$ & MYH7 (4625) \\
\hline $\begin{array}{l}\text { Hydroxy- } \delta \text {-5-steroid } \\
\text { dehydrogenase }\end{array}$ & $\downarrow$ & 79 & Biosynthesis of steroid hormones, polymorphisms related to prostate cancer & HSD3B2 (3284) \\
\hline $\begin{array}{l}\text { Hydroxy- } \delta \text {-5-steroid } \\
\text { dehydrogenase }\end{array}$ & $\downarrow$ & 30 & Biosynthesis of steroid hormones, diagnostic trophoblastic marker & HSD3B1 (3283) \\
\hline $\begin{array}{l}\text { similar to } 3 \beta \text {-hydroxysteroid } \\
\text { dehydrogenase }\end{array}$ & $\downarrow$ & 28 & Pseudogene & $\begin{array}{l}\text { LOC391081 } \\
(391081)\end{array}$ \\
\hline- & $\downarrow$ & 24 & unknown & CR627415 \\
\hline Butyrylcholinesterase & $\downarrow$ & 21 & $\begin{array}{l}\text { Homozygoutics sustain prolonged apnea after administration of the muscle relaxant } \\
\text { suxamethonium }\end{array}$ & BCHE (590) \\
\hline Neuronal pentraxin & $\downarrow$ & 19 & $\begin{array}{l}\text { Excitatory synapse remodelling, mediate neuronal death induced by reduction in } \\
\text { neuronal activity in mature neurons }\end{array}$ & NPTX1 (4884) \\
\hline Dipeptidyl-peptidase 6 & $\downarrow$ & 18 & $\begin{array}{l}\text { Binds and alters specific voltage-gated potassium channels expression and } \\
\text { biophysical properties }\end{array}$ & DPP6 (1804) \\
\hline $\begin{array}{l}\text { ATP-binding cassette, sub-family } \\
\text { G }\end{array}$ & $\downarrow$ & 17 & $\begin{array}{l}\text { Breast cancer resistance protein, xenobiotic transporter may play a major role in } \\
\text { multi-drug resistance }\end{array}$ & ABCG2 (9429) \\
\hline Insulin like-5 & $\downarrow$ & 17 & Relaxin/Insulin family, ligand for GPCR142 & INSL5 (10022) \\
\hline Regenerating islet-derived $1 \beta$ & $\downarrow$ & 16 & Highly similar to REG1A protein (islet cell regeneration and diabetogenesis) & REG1B (5968) \\
\hline
\end{tabular}


Table 4 Genes listed according to the magnitude of most altered expression in tumor tissue of high intrinsic COX-2 expression

\begin{tabular}{|c|c|c|c|c|}
\hline Gene & $\uparrow / \downarrow$ & FC & Function & $\begin{array}{l}\text { Gene Symbol } \\
\text { (GenelD) }\end{array}$ \\
\hline Unknown & $\uparrow$ & 156 & unknown & W60781 \\
\hline Myosin & $\uparrow$ & 107 & Muscle, heavy polypeptide 2 & MYH2 (4620) \\
\hline Desmin & $\uparrow$ & 49 & Muscle filament & DES (1674) \\
\hline Creatine kinase & $\uparrow$ & 46 & Muscle, energy homeostasis, serum marker for myocardial infarction & CKM (1158) \\
\hline Troponin T type 3 & $\uparrow$ & 41 & Skeletal & TNNT3 (7140) \\
\hline Actin $\alpha$, cardiac & $\uparrow$ & 37 & Muscle, contractile, cell motility & ACTC1 (70) \\
\hline Actin $\alpha 1$, skeletal & $\uparrow$ & 35 & Cell motility, structure and integrity & ACTA1 (58) \\
\hline Synaptopodin 2 & $\uparrow$ & 28 & $\begin{array}{l}\text { Cell-shape regulation, homolog with Myopodin (a tumor suppressor; inhibits growth } \\
\text { and metastasis) }\end{array}$ & SYNPO2 (171024) \\
\hline Nebulin & $\uparrow$ & 25 & Cytoskeletal matrix & NEB (4703) \\
\hline Calponin & $\uparrow$ & 23 & Differentiation marker, reduced in tumor vessels associated with tumor progression & CNN1 (1264) \\
\hline Growth diff. factor 10 & $\downarrow$ & 28 & Regulation of cell growth and differentiation & GDF10 (2662) \\
\hline Unc-13 homolog A & $\downarrow$ & 19 & diacylglycerol and phorbol ester receptors, essential role in synaptic vesicle priming & UNC13A (23025) \\
\hline LOC553137 & $\downarrow$ & 16 & miscRNA, unknown function & $\begin{array}{l}\text { LOC553137 } \\
(553137)\end{array}$ \\
\hline $\begin{array}{l}\text { Melanoma antigen family B, } \\
2\end{array}$ & $\downarrow$ & 14 & $\begin{array}{l}\text { Tumor-associated antigen, expressed only in testis and tumors, regulated by } \\
\text { demethylation }\end{array}$ & MAGEB2 (4113) \\
\hline $\begin{array}{l}\text { Chondrosarcoma associated } \\
\text { gene } 1\end{array}$ & $\downarrow$ & 13 & Tumor antigen, expressed in testis and in chondrosarcomas & CSAG1 (158511) \\
\hline Folate receptor 1 & $\downarrow$ & 13 & Involvement in cancer prognosis & FOLR1 (2348) \\
\hline Renin & $\downarrow$ & 13 & Blood pressure and electrolyte balance & REN (5972) \\
\hline Small proline-rich protein 3 & $\downarrow$ & 12 & $\begin{array}{l}\text { Epithelial homeostatis, aberrant expression contribute to tumorigenesis of esophageal } \\
\text { squamous cell carcinoma }\end{array}$ & SPRR3 (6707) \\
\hline Heat shock $27 \mathrm{kDa}$ protein 3 & $\downarrow$ & 12 & Muscle & HSPB3 (8988) \\
\hline Chromogranin B & $\downarrow$ & 11 & Precursor for biological active peptides, involved early in breast cancer & CHGB (1114) \\
\hline
\end{tabular}

expression in tumor tissue (Table 7). Table 8 describes genes with significantly altered expression of transcription factors and external cell signaling factors in normal mucosa from patients with tumors of increased COX-2 expression. IL1- $\beta$, IL6, and iNOS were up-regulated, probably inducing a variety of transcription factors.

\section{Pathway analysis}

Significantly altered metabolic and signaling pathways (FC 1.5) in tumors with high COX-2 expression were mainly related to immunity according to algorithm analyses (GeneSpring GX 10, Agilent). Five genes that were significantly changed in arrays (AKT1, CARD11, IL1B, IL6, and TRA@) and involved in significantly changed pathways according to the algorithm analyses (TCR, BCR, IL1, and IL6) were tested individually (Table 9). All results from individual PCR analyses agreed with array results with one exception; in tumor tissue with high compared to low COX-2 expression AKT1 expression was significantly higher in PCR analyses, with opposite direction in array analysis.

\section{DNA methylation}

A majority of tumor tissue specimens displayed no methylation of the promoter region of the COX-2 gene in tumor tissue; only 2 tumors showed methylation of the promoter region (low COX-2, Dukes B tumors with intermediate differentiation). Methylation of the promoter region of the COX-2 gene was not observed in any of the normal colon mucosa specimens.

\section{Discussion}

Increased prostanoid activity is a well recognized characteristic of colorectal cancer $[4,8,10,18-20]$. Early, it was claimed that such tumors have increased COX-2 expression deduced from immunohistochemical evaluations of tumor tissue specimens. More recent investigations have however emphasized that increased COX-2 expression in colorectal cancer is preferentially a local phenomenon with uneven distribution among transformed cells without overall increased tissue content [11]. These findings imply heterogenous cell clones or that other factor are responsible for either up- or down-regulation of $\mathrm{COX}-2$ 
Table 5 Genes listed according to the magnitude of most altered expression in normal mucosa from patients with tumors of high intrinsic COX-2 expression

\begin{tabular}{|c|c|c|c|c|}
\hline Gene & $\uparrow / \downarrow$ & FC & Function & $\begin{array}{l}\text { Gene Symbol } \\
\text { (GenelD) }\end{array}$ \\
\hline $\begin{array}{l}\text { Pancreatic derived factor } \\
\text { (PANDER) }\end{array}$ & $\uparrow$ & 79 & Cytokine, induces apoptosis of alpha and beta cells, implicated in diabetes & FAM3B (54097) \\
\hline $\begin{array}{l}\text { Regenerating islet-derived } 1 \\
\alpha\end{array}$ & $\uparrow$ & 40 & $\begin{array}{l}\text { Secreted by the exocrine pancreas, associated with islet cell regeneration and } \\
\text { diabetogenesis }\end{array}$ & REG1A (5967) \\
\hline $\begin{array}{l}\text { Ribosomal protein } \mathrm{S4}, \mathrm{Y}- \\
\text { linked } 2\end{array}$ & $\uparrow$ & 40 & Translation & $\begin{array}{l}\text { RPS4Y2 } \\
(140032)\end{array}$ \\
\hline $\begin{array}{l}\text { Serpin peptidase inhibitor, } \\
\text { ovalbumin }\end{array}$ & $\uparrow$ & 35 & $\begin{array}{l}\text { Cytoprotective, cell survival factor, monocyte regulation, potential cancer marker (elevated } \\
\text { in plasma) }\end{array}$ & $\begin{array}{l}\text { SERPINB2 } \\
(5055)\end{array}$ \\
\hline $\begin{array}{l}\text { Nitric oxide synthase } 2, \\
\text { inducible }\end{array}$ & $\uparrow$ & 19 & $\begin{array}{l}\text { reactive free radical, biologic mediator in several processes, incl. neurotransmission, } \\
\text { antimicrobial and antitumoral activities }\end{array}$ & NOS2A (4843) \\
\hline Pentraxin-related gene & $\uparrow$ & 16 & Immune response, inflammation, rapidly induced by IL-1 $\beta$ & PTX3 (5806) \\
\hline $\begin{array}{l}\text { Regenerating islet-derived } 1 \\
\beta\end{array}$ & $\uparrow$ & 16 & highly similar to REG1A protein & REG1B (5968) \\
\hline $\begin{array}{l}\text { Hydroxy-delta-5-steroid } \\
\text { dehydrogenase }\end{array}$ & $\uparrow$ & 10 & Biosynthesis of steroid hormones, polymorphisms related to prostate cancer & HSD3B2 (3284) \\
\hline $\begin{array}{l}\text { Hydroxy-delta-5-steroid } \\
\text { dehydrogenase }\end{array}$ & $\uparrow$ & 10 & Biosynthesis of steroid hormones, diagnostic trophoblastic marker & HSD3B1 (3283) \\
\hline ADAM metallopeptidase & $\uparrow$ & 10 & $\begin{array}{l}\text { cleavage of proteoglycans, control of organ shape during development, and inhibition of } \\
\text { angiogenesis }\end{array}$ & $\begin{array}{l}\text { ADAMTS9 } \\
\text { (56999) }\end{array}$ \\
\hline Unknown & $\downarrow$ & 15 & unknown & ENST00000343 \\
\hline 6-phosphofructo-2-kinase & $\downarrow$ & 13 & Produce fructose $2,6-\mathrm{P}(2)$, involved in Warburg effect & PFKFB3 (5209) \\
\hline hemoglobin, $\gamma \mathrm{A}$ & $\downarrow$ & 8 & Normally expressed in the fetal liver, spleen and bone marrow & HBG1 (3047) \\
\hline matrix metallopeptidase 7 & $\downarrow$ & 8 & Breakdown of extracellular matrix, metastasis & MMP7 (4316) \\
\hline Fc receptor-like 4 & $\downarrow$ & 7 & Immune regulation & FCRL4 (83417) \\
\hline Chemokine receptor 5 & $\downarrow$ & 6 & B cell migration and localization & BLR1 (643) \\
\hline Fibroblast growth factor 5 & $\downarrow$ & 6 & $\begin{array}{l}\text { Mitogenic and cell survival activities, involved in a variety of biological processes, incl. cell } \\
\text { growth, morphogenesis, tissue repair, tumor growth and invasion, oncogene }\end{array}$ & FGF5 (2250) \\
\hline $\begin{array}{l}\text { Family with sequence } \\
\text { similarity } 129 \text {, member } C\end{array}$ & $\downarrow$ & 6 & $\begin{array}{l}\text { B-cell novel protein, BCNP1 completely unknown protein with } 3 \text { predicted transmembrane } \\
\text { domains }\end{array}$ & $\begin{array}{l}\text { FAM129C } \\
(199786)\end{array}$ \\
\hline selectin $\mathrm{L}$ & $\downarrow$ & 6 & Leukocyte-endothelial cell interactions & SELL (6402) \\
\hline Zinc finger protein & $\downarrow$ & 5 & DNA binding & $\begin{array}{l}\text { ZNF683 } \\
(257101)\end{array}$ \\
\hline
\end{tabular}

$\uparrow$ increased expression.

$\downarrow$ decreased expression.

in malignant cells. It is also important to underline that increased COX-2 expression in tumor tissue may well be confined to stroma and host cells. Such a complex condition supports cross-talk among cells with prostanoids as signals through specific receptors. Our previous investigations have demonstrated a statistically significant relationship between COX-2 expression and tumor tissue production of $\mathrm{PGE}_{2}$, which is elevated in colon cancer tissue [11]. These kinds of findings agree with information that both primary and secondary intervention with cyclooxygenase inhibitors influenced on both local tumor growth and systemic effects in experimental and clinical cancer [4]. Of particular interest may be previous observations that subtype $\mathrm{EP}_{2}$ receptor expression in colon cancer tissue predicted reduced survival [2]. Seen together, it seems that induction of COX-2 is a key-factor behind progression of epithelial cell transformation to invasive cancer in colon mucosa. This logic has been practically explored evaluating the role of COX-2 inhibition on epithelial dysplasia in esophageal mucosa, although without consistent results [21]. However, understanding in part complex cell to cell interactions and signaling in composed tissues it should not be expected to be isolated single factors behind local and systemic tumor progression. Therefore, we intended to evaluate relationships between high COX-2 expression in colon cancer tissue to other factors of known importance for tumor cell division, apoptosis, and metastasis. In this perspective microarray screening should be rewarding.

With this purpose we have quantified COX-2 expression in primary tumors from 48 unselected patients with 
Table 6 Significant alterations in expression of previously reported important transcription factors in tumors of high intrinsic COX-2 expression

\begin{tabular}{|c|c|c|c|c|c|}
\hline Gene & Product & FC 1.5 & FC 2.0 & FC 3.0 & Reference $^{a}$ \\
\hline TFAP2C & $\mathrm{AP}-2 \gamma$ & $\downarrow$ & - & - & {$[12]$} \\
\hline TFAP2E & $\mathrm{AP}-2 \varepsilon$ & - & - & - & {$[12]$} \\
\hline ATF1 & ATF1 & - & - & - & [13] \\
\hline ATF2 & ATF2/CREB2 & - & - & - & {$[13]$} \\
\hline ATF3 & ATF3/AP1 & $\uparrow$ & - & - & [13] \\
\hline BATF & B-ATF & - & - & - & [13] \\
\hline CREBBP & CBP/p300 co-activator & - & - & - & {$[12]$} \\
\hline CDX2 & $\mathrm{CDX} 2$ & $\downarrow$ & - & - & [29] \\
\hline CEBPA & $C / E B P-\alpha$ & - & - & - & [13] \\
\hline CEBPB & C/EBP- $\beta$ & - & - & - & {$[13]$} \\
\hline CEBPD & C/EBP- $\delta$ & $\uparrow$ & $\uparrow$ & - & {$[13]$} \\
\hline CREB5 & CRE-BPA & - & - & - & {$[13]$} \\
\hline CREB1 & CREB & - & - & - & [13] \\
\hline ELK1 & Elk-1 & $\downarrow$ & - & - & [13] \\
\hline FOS & C-Fos/AP1 & $\uparrow$ & - & - & {$[12]$} \\
\hline FOSB & Fos-B/AP1 & $\uparrow$ & $\uparrow$ & $\uparrow$ & {$[12]$} \\
\hline FOSL1 & Fra-1/AP1 & - & - & - & {$[12]$} \\
\hline FOSL2 & Fra-2/AP1 & - & - & - & {$[12]$} \\
\hline DNAJC12 & JDP1 & - & - & - & [12] \\
\hline JDP2 & JDP2 & $\uparrow$ & - & - & {$[12]$} \\
\hline JUN & Jun/AP1 & - & - & - & {$[12]$} \\
\hline JUNB & JunB/AP1 & - & - & - & {$[12]$} \\
\hline JUND & JunD/AP1 & $\uparrow$ & - & - & {$[12]$} \\
\hline MAF & c-Maf/AP1 & $\uparrow$ & $\uparrow$ & - & {$[12]$} \\
\hline NFATC1 & NFATC1/NFAT2 & - & - & - & {$[12]$} \\
\hline NFATC4 & NFAT3 & - & - & - & {$[12]$} \\
\hline NFATC3 & NFAT4 & - & - & - & {$[12]$} \\
\hline NFAT5 & NFAT5 & - & - & - & {$[12]$} \\
\hline NFKB1 & NF- $\kappa$ B, p105/p50 & - & - & - & {$[12,13]$} \\
\hline NFKB2 & $N F-\kappa B, p 100$ & - & - & - & {$[12,13]$} \\
\hline RELA & NF- $\kappa$ B, RelA (p65) & - & - & - & {$[12,13]$} \\
\hline RELB & NF- $\kappa \mathrm{B}$, RelB & - & - & - & {$[12,13]$} \\
\hline REL & NF- $\kappa$ B, c-Rel & - & - & - & {$[12,13]$} \\
\hline NFKBIA & $\mathrm{NF}-\kappa \mathrm{B}, \mid \kappa \mathrm{B} \alpha$ & $\uparrow$ & $\uparrow$ & - & {$[12,13]$} \\
\hline NFKBIB & $N F-\kappa B, \mid \kappa B \beta$ & - & - & - & {$[12,13]$} \\
\hline NFKBIE & $\mathrm{NF}-\kappa \mathrm{B}, \mid \kappa \mathrm{B} \varepsilon$ & - & - & - & {$[12,13]$} \\
\hline CHUK & $N F-\kappa B, I K K-\alpha$ & - & - & - & {$[12,13]$} \\
\hline IKBKB & $N F-\kappa B, I K K-\beta$ & - & - & - & {$[12,13]$} \\
\hline IKBKG & $N F-\kappa B, I K K-\gamma$ & - & - & - & {$[12,13]$} \\
\hline TP53 & p53 & $\downarrow$ & $\downarrow$ & - & {$[30]$} \\
\hline ETV4 & PEA3 & $\downarrow$ & - & - & [13] \\
\hline PPARA & PPAR $\alpha$ & - & - & - & [12] \\
\hline PPARD & PPAR $\beta / \delta$ & - & - & - & {$[12]$} \\
\hline PPARG & PPAR $\gamma$ & - & - & - & {$[12]$} \\
\hline SP1 & SP-1 & - & - & - & [12] \\
\hline
\end{tabular}

Table 6 Significant alterations in expression of previously reported important transcription factors in tumors of high intrinsic COX-2 expression (Continued)

\begin{tabular}{llllll}
\hline TBP & TATA-binding protein & - & - & - & {$[12]$} \\
\hline TCF4 & TCF4 & $\uparrow$ & $\uparrow$ & - & {$[13]$} \\
\hline
\end{tabular}

AP- $2 \alpha$, AP-2 $\beta$, AP- $2 \delta$, NFAT1 and Retinoic acid receptor were also tested, but no expression were found.

$\uparrow$ increased expression; $\downarrow$ decreased expression; FC is log2 fold changes. a published report with emphasis on transcription factor in regulation of COX-2 gene.

R0 resected primary tumors. Then, tumor tissue with 10 highest and lowest COX-2 expressions was chosen for subsequent hybridization in various combinations. Such cross-combinations of tissues for microarray expression analyses revealed that tumors with high intrinsic COX-2 expression displayed pronounced up-regulation of genes related to muscle fibers and cytoskeleton matrix, perhaps reflecting matrix remodeling including angiogenesis. By contrast, down-regulated genes in such tumors were more related to functional proteins and eventual cellular antigens (Table 4). Similar findings were

Table 7 Significant alterations in expression of previously reported important external cell signaling factors and enzymes in tumors of high intrinsic COX-2 expression

\begin{tabular}{|c|c|c|c|c|c|}
\hline Gene & Product & $\begin{array}{l}\text { FC } \\
1.5\end{array}$ & $\begin{array}{l}\text { FC } \\
2.0\end{array}$ & $\begin{array}{l}\mathrm{FC} \\
3.0\end{array}$ & Reference $^{a}$ \\
\hline DNMT1 & DNA MTase 1 & - & - & - & [26] \\
\hline DNMT3A & DNA MTase 3A & $\uparrow$ & $\uparrow$ & - & [26] \\
\hline DNMT3B & DNA MTase 3B & - & - & - & [26] \\
\hline MDM2 & hdm2 & - & - & - & [30] \\
\hline HPGD & HPGD & - & - & - & {$[1]$} \\
\hline HNRPD & HuR & - & - & - & {$[31]$} \\
\hline IL1B & IL $1 \mathrm{~b}$ & $\uparrow$ & $\uparrow$ & - & {$[32,33]$} \\
\hline IL6 & IL6 & $\uparrow$ & $\uparrow$ & $\uparrow$ & [34] \\
\hline IL6R & IL6 receptor & $\uparrow$ & - & - & {$[34]$} \\
\hline NOS2A & iNOS & - & - & - & [13] \\
\hline MAPK14 & p38 MAPK & - & - & - & {$[35]$} \\
\hline PTGES & mPGES-1 & - & - & - & {$[1]$} \\
\hline PRKCB1 & Protein kinas $C \beta 1$ & $\uparrow$ & $\uparrow$ & $\uparrow$ & {$[12]$} \\
\hline RALA & Ras family (oncogene) & - & - & - & {$[12]$} \\
\hline RASA4 & $\begin{array}{l}\text { Ras p21 protein } \\
\text { activator }\end{array}$ & - & - & - & {$[12]$} \\
\hline RASSF1 & Ras ass. (tumor supr.) & - & - & - & {$[12]$} \\
\hline RIN2 & Ras and Rab interact. 2 & - & - & - & {$[12]$} \\
\hline TINP1 & TGF- $\beta$ & - & - & - & [13] \\
\hline TNF & TNF- $\alpha$ & $\uparrow$ & - & - & [13] \\
\hline
\end{tabular}


Table 8 Significant alterations in expression of transcription factors and cell signaling factors in normal colon mucosa from patients with tumors of high intrinsic COX-2 expression

\begin{tabular}{llccc}
\hline Gene & Product & FC $\mathbf{1 . 5}$ & FC $\mathbf{2 . 0}$ & FC $\mathbf{3 . 0}$ \\
\hline PTGS2 & COX-2 & $\uparrow$ & $\uparrow$ & $\uparrow$ \\
\hline Transcription & & & & \\
\hline ATF3 & ATF3/AP1 & $\uparrow$ & - & - \\
\hline CEBPD & C/EBP- $\delta$ & $\uparrow$ & $\uparrow$ & - \\
\hline CREB1 & CREB & $\uparrow$ & - & - \\
\hline FOSB & FOS-B/AP1 & $\uparrow$ & $\uparrow$ & - \\
\hline DNAJC12 & JDP1 & $\uparrow$ & - & - \\
\hline NFATC1 & NFATC1/NFAT2 & $\downarrow$ & - & - \\
\hline PPARG & PPAR $\gamma$ & $\downarrow$ & - & - \\
\hline BATF & B-ATF & $\downarrow$ & - & - \\
\hline External cell factors & IL1b & $\uparrow$ & $\uparrow$ & $\uparrow$ \\
\hline IL1B & IL6 & $\uparrow$ & $\uparrow$ & $\uparrow$ \\
\hline IL6 & iNOS & $\uparrow$ & $\uparrow$ & $\uparrow$ \\
\hline NOS2A & & & \\
\hline
\end{tabular}

All factors listed in Table 6 and 7 were evaluated.

observed in comparisons between tumor tissue and normal mucosa from the corresponding patients (Table 3). Most interesting was however, findings that normal colon tissue from patients with high intrinsic COX-2 expression in tumor tissue revealed pronounced up- and down-regulation of several gene functions. Such observations led to the conclusion that colon tissue in patients with colon cancer is significantly altered in regards to functional aspects either primarily or secondary to the appearance of manifest tumor. Analysis of significantly altered pathways at high COX-2 displayed that most alterations were related to immune reactions in the present and previous analyses [22]. This confirms our previous results based on an alternative approach where preoperative COX inhibition by indomethacin mainly affected genes and pathways that involved the immunity $[22,23]$.

It may be rewarding to understand the control of COX-2 gene expression behind complex in vivo interactions as emphasized. According to this line we evaluated a large number of proposed genes with importance for COX-2 expression as listed in Table 6. Fourteen out of 47 genes were found to have significantly altered expression defined at least as 1.5 fold change compared to normal mucosa or by chance variation in transcript expression. Fos-B/AP1 expression displayed the most pronounced alteration of up-regulated transcripts among transcription factors. A transcription complex known to regulate COX-2 gene expression via binding to CRE-sites in the promoter region is Activator protein 1 (AP-1), which consists of homo- or heterodimers of JUN- and FOS-families with roles in several different cancers. In colorectal cancer AP-1 may be activated by either K-RAS mutation or via Wnt signals. Different genes are transcribed controlling biological activities such as proliferation, apoptosis and differentiation depending on the sub-components of AP-1 [24,25]. Six of 19 factors with emphasized importance for external cell signaling were up-regulated in tumor tissue of high intrinsic COX-2 expression (Table 7). As expected, such experiments confirmed no significant transcript with decreased expression. IL6 and protein kinas C $\beta 1$ appeared most up-regulated in such cross hybridizations, although transcription of NF- $\kappa \mathrm{B}$ was not elevated. In this context it is important to emphasize that protein and gene activation may occur despite evidence of unchanged transcription levels, usually subsequent to phosphorylation changes. Again, it was observed that 9 transcription factors and IL1 $\beta$, IL6 and iNOS were significantly altered in normal colon tissue from patients with tumors of high intrinsic COX-2 expression. Individual confirmation of array results by PCR determinations displayed also a significantly higher expression of

Table 9 Gene expressions in tumor tissue with high COX-2 expression compared to tumor tissue with low COX-2 expression confirmed by q-PCR

\begin{tabular}{|c|c|c|c|c|c|c|c|c|c|c|}
\hline & \multicolumn{2}{|c|}{ CARD 11} & \multicolumn{2}{|c|}{ TRA@ } & \multicolumn{2}{|c|}{ IL6 } & \multicolumn{2}{|c|}{ IL1B } & \multicolumn{2}{|c|}{ AKT1 } \\
\hline & $\begin{array}{c}\text { High } \\
\text { COX-2 (9) }\end{array}$ & $\begin{array}{c}\text { Low } \\
\text { COX-2 (9) }\end{array}$ & $\begin{array}{c}\text { High } \\
\text { COX-2 (9) }\end{array}$ & $\begin{array}{c}\text { Low } \\
\text { COX-2 (9) }\end{array}$ & $\begin{array}{c}\text { High } \\
\text { COX-2 (9) }\end{array}$ & $\begin{array}{c}\text { Low } \\
\text { COX-2 (9) }\end{array}$ & $\begin{array}{c}\text { High } \\
\text { COX-2 (9) }\end{array}$ & $\begin{array}{c}\text { Low } \\
\text { COX-2 (9) }\end{array}$ & $\begin{array}{c}\text { High } \\
\text { COX-2 (9) }\end{array}$ & $\begin{array}{c}\text { Low } \\
\text { COX-2 (9) }\end{array}$ \\
\hline Mean & $0.40 \pm 0.08$ & $0.42 \pm 0.24$ & $2.87 \pm 0.63$ & $0.55 \pm 0.14$ & $1.97 \pm 0.79$ & $0.09 \pm 0.03$ & $1.61 \pm 0.49$ & $0.27 \pm 0.06$ & $1.09 \pm 0.13$ & $0.62 \pm 0.07$ \\
\hline Median & 0.39 & 0.07 & 3.12 & 0.44 & 0.87 & 0.05 & 1.01 & 0.21 & 0.96 & 0.59 \\
\hline Variance & 0.06 & 0.50 & 3.57 & 0.18 & 5.65 & 0.008 & 2.16 & 0.04 & 0.14 & 0.04 \\
\hline P-value* & \multicolumn{2}{|c|}{ ns } & \multicolumn{2}{|c|}{0.002} & \multicolumn{2}{|c|}{0.03} & \multicolumn{2}{|c|}{0.02} & \multicolumn{2}{|c|}{0.005} \\
\hline
\end{tabular}

*ANOVA analysis.

CARD11 = caspase recruitment domain family, member 11.

TRA@ = T cell receptor alpha locus.

IL6 = Interleukin 6.

IL1B = Interleukin $1 \beta$.

AKT1 $=\mathrm{v}$-akt murine thymoma viral oncogene homolog 1 or protein kinase $\mathrm{B}$. 
IL1 $\beta$ and IL6 at high COX-2. This phenomenon demonstrates that overall COX-2 expression in primary colorectal carcinoma probably includes primary and secondary alterations in tumor un-involved colon tissue.

It is well recognized that methylation of $\mathrm{CpG}$ island located within promoter regions of genes may silence gene expression, described as a hallmark in human cancer. This represents findings early during carcinogenesis and is maintained by DNA methyltransferase (DNMTs) [26]. Such methylation of the COX-2 promoter region may be associated with loss of gene expression as reported for gastric cancer [15,27]. Similar evidence has been reported for COX-2 gene expression in colorectal cancer [27,28], although, statistical evaluations of reported observations do not give the impression that COX-2 expression in colon cancer tissue is related to COX-2 promoter methylation. Accordingly, we did not observe significant methylation in two well-defined parts of the COX-2 promoter region in tumor and normal colon tissues. However, DNA methyltransferase was expressed at increased levels in tumor tissue compared to the corresponding normal colon tissue. Therefore, it is unlikely that promoter methylation was a significant factor behind the lack of COX-2 expression in presently investigated areas of colon cancer tissue. It remains to be determined how COX-2 is either induced in tumor tissue with intrinsic high COX-2 expression or downregulated in tumor cells with correspondingly low overall COX-2 expression to provide the well-recognised scattered pattern of expression observed in immunohistochemical cross tissue sections. Important is our observation that COX-2 expression in normal colon tissue was also significantly increased in patients with tumors of high COX-2 expression. This points to the possibility, that the mucosa or entire colon tissue may be altered as a general phenomenon in patients with certain kind of colon tumors. Perhaps, the inflammatory activation by some kind of bacterial flora(s) could be a speculative guess.

\section{Conclusion}

Our present study emphasized and confirmed our previous observations that increased $\mathrm{COX}-2$ expression or tissue content is overall not a unanimous finding in colorectal cancer tissue. A scattered presence of COX-2 may rather represent different cell clones or different local conditions at the cellular level. Both transcription and external cell signaling factors were significantly altered as covariates to COX-2 expression in colon cancer tissue. DNA methylation of the COX-2 promoter region did not seem to be a significant factor behind COX-2 expression in either tumor tissue or normal colon tissue in the present material. Our results confirm that both local and systemic inflammation promote tumor growth and disease progression.

\section{Abbreviations}

COX: cyclooxygenase; RIN: RNA Integrity number.

\section{Acknowledgements}

Supported in parts by grants from the Swedish Cancer Society (2014), the Swedish Research Council (08712), Assar Gabrielsson Foundation (AB Volvo), Jubileumskliniken Foundation, IngaBritt \& Arne Lundberg Research

Foundation, Swedish and Gothenburg Medical Societies, the Medical Faculty, University of Gothenburg and Sahlgrenska University Hospital Foundation. We would like to thank the Swegene Gothenburg Genomics resource unit for providing access to the ABI 3730 Sequencer.

\section{Author details}

${ }^{1}$ Department of Surgery, Institute of Clinical Sciences, Sahlgrenska Academy, Sahlgrenska University Hospital, Gothenburg, Sweden. ²Department of Clinical Genetics, Institute of Biomedicine, University of Gothenburg, Sweden.

\section{Authors' contributions}

AG carried out the study design, gene expression studies, DNA methylation and drafted the manuscript. HC participated in DNA methylation analysis. MA participated in extraction of RNA/DNA and carried out gene expression experiment. $\mathrm{CL}$ participated in study design and gene expression analysis. $\mathrm{KKL}$ participated in gene expression analysis. $\mathrm{KL}$ conceived of the study and participated in study design and helped drafted the manuscript.

All authors have read and approved the manuscript.

\section{Competing interests}

The authors declare that they have no competing interests.

Received: 2 February 2011 Accepted: 13 June 2011

Published: 13 June 2011

\section{References}

1. Greenhough A, Smartt HJ, Moore AE, Roberts HR, Williams AC, Paraskeva C, Kaidi A: The COX-2/PGE2 pathway: key roles in the hallmarks of cancer and adaptation to the tumour microenvironment. Carcinogenesis 2009, 30(3):377-386

2. Gustafsson A, Hansson E, Kressner U, Nordgren S, Andersson M, Wang W, Lonnroth C, Lundholm K: EP1-4 subtype, COX and PPAR gamma receptor expression in colorectal cancer in prediction of disease-specific mortality. Int J Cancer 2007, 121(2):232-240.

3. Gustafsson A, Hansson E, Kressner U, Nordgren S, Andersson M, Lonnroth C, Lundholm K: Prostanoid receptor expression in colorectal cancer related to tumor stage, differentiation and progression. Acta Oncol 2007, 1-6.

4. Cahlin C, Gelin J, Andersson M, Lonnroth C, Lundholm K: The effects of non-selective, preferential-selective and selective COX-inhibitors on the growth of experimental and human tumors in mice related to prostanoid receptors. Int J Oncol 2005, 27(4):913-923.

5. Thun MJ, Namboodiri MM, Calle EE, Flanders WD, Heath CW Jr: Aspirin use and risk of fatal cancer. Cancer Res 1993, 53(6):1322-1327.

6. Muscat JE, Stellman SD, Wynder EL: Nonsteroidal antiinflammatory drugs and colorectal cancer. Cancer 1994, 74(7):1847-1854.

7. Sandler RS, Halabi S, Baron JA, Budinger S, Paskett E, Keresztes R, Petrelli N, Pipas JM, Karp DD, Loprinzi CL, et al: A randomized trial of aspirin to prevent colorectal adenomas in patients with previous colorectal cancer. N Engl J Med 2003, 348(10):883-890.

8. Gelin J, Andersson C, Lundholm K: Effects of indomethacin, cytokines, and cyclosporin A on tumor growth and the subsequent development of cancer cachexia. Cancer Res 1991, 51(3):880-885.

9. Lundholm K, Gelin J, Hyltander A, Lonnroth C, Sandstrom R, Svaninger G, Korner U, Gulich M, Karrefors I, Norli B, et al: Anti-inflammatory treatment may prolong survival in undernourished patients with metastatic solid tumors. Cancer Res 1994, 54(21):5602-5606.

10. Hull MA, Ko SC, Hawcroft G: Prostaglandin EP receptors: targets for treatment and prevention of colorectal cancer? Mol Cancer Ther 2004, 3(8):1031-1039. 
11. Cahlin C, Lonnroth C, Arvidsson A, Nordgren S, Lundholm K: Growth associated proteins in tumor cells and stroma related to disease progression of colon cancer accounting for tumor tissue PGE2 content Int J Oncol 2008, 32(4):909-918.

12. Chun KS, Surh YJ: Signal transduction pathways regulating cyclooxygenase-2 expression: potential molecular targets for chemoprevention. Biochem Pharmacol 2004, 68(6):1089-1100.

13. Tsatsanis C, Androulidaki A, Venihaki M, Margioris AN: Signalling networks regulating cyclooxygenase-2. Int J Biochem Cell Biol 2006 , 38(10):1654-1661.

14. Han W, Cauchi S, Herman JG, Spivack SD: DNA methylation mapping by tag-modified bisulfite genomic sequencing. Anal Biochem 2006, 355(1):50-61.

15. Hur K, Song SH, Lee HS, Ho Kim W, Bang YJ, Yang HK: Aberrant methylation of the specific $C p G$ island portion regulates cyclooxygenase-2 gene expression in human gastric carcinomas. Biochem Biophys Res Commun 2003, 310(3):844-851.

16. Tusnady GE, Simon I, Varadi A, Aranyi T: BiSearch: primer-design and search tool for PCR on bisulfite-treated genomes. Nucleic Acids Res 2005, 33(1):e9.

17. Bock C, Reither S, Mikeska T, Paulsen M, Walter J, Lengauer T: BiQ Analyzer: visualization and quality control for DNA methylation data from bisulfite sequencing. Bioinformatics 2005, 21(21):4067-4068.

18. Cao Y, Prescott SM: Many actions of cyclooxygenase-2 in cellular dynamics and in cancer. J Cell Physiol 2002, 190(3):279-286.

19. Pradono P, Tazawa R, Maemondo M, Tanaka M, Usui K, Saijo Y, Hagiwara K, Nukiwa T: Gene transfer of thromboxane A(2) synthase and prostaglandin I(2) synthase antithetically altered tumor angiogenesis and tumor growth. Cancer Res 2002, 62(1):63-66.

20. Wang D, Dubois RN: Prostaglandins and cancer. Gut 2006, 55(1):115-122.

21. Zhi H, Wang L, Zhang J, Zhou C, Ding F, Luo A, Wu M, Zhan Q, Liu Z: Significance of COX-2 expression in human esophageal squamous cell carcinoma. Carcinogenesis 2006, 27(6):1214-1221.

22. Lonnroth $C$, Andersson M, Arvidsson A, Nordgren S, Brevinge $H$, Lagerstedt K, Lundholm K: Preoperative treatment with a non-steroidal anti-inflammatory drug (NSAID) increases tumor tissue infiltration of seemingly activated immune cells in colorectal cancer. Cancer Immun 2008, 8:5.

23. Gustafsson A, Andersson M, Lagerstedt K, Lonnroth C, Nordgren S, Lundholm K: Receptor and enzyme expression for prostanoid metabolism in colorectal cancer related to tumor tissue PGE2. Int J Oncol 2010, 36(2):469-478.

24. Ashida R, Tominaga K, Sasaki E, Watanabe T, Fujiwara $Y$, Oshitani N, Higuchi K, Mitsuyama S, Iwao H, Arakawa T: AP-1 and colorectal cancer. Inflammopharmacology 2005, 13(1-3):113-125.

25. Grau R, Iniguez MA, Fresno M: Inhibition of activator protein 1 activation, vascular endothelial growth factor, and cyclooxygenase-2 expression by 15-deoxy-Delta12,14-prostaglandin $\mathrm{J} 2$ in colon carcinoma cells: evidence for a redox-sensitive peroxisome proliferator-activated receptor-gammaindependent mechanism. Cancer Res 2004, 64(15):5162-5171.

26. Egger G, Liang G, Aparicio A, Jones PA: Epigenetics in human disease and prospects for epigenetic therapy. Nature 2004, 429(6990):457-463.

27. Castells A, Paya A, Alenda C, Rodriguez-Moranta F, Agrelo R, Andreu M, Pinol V, Castellvi-Bel S, Jover R, Llor X, et al: Cyclooxygenase 2 expression in colorectal cancer with DNA mismatch repair deficiency. Clin Cancer Res 2006, 12(6):1686-1692.

28. Toyota M, Shen L, Ohe-Toyota M, Hamilton SR, Sinicrope FA, Issa JP. Aberrant methylation of the Cyclooxygenase 2 CpG island in colorectal tumors. Cancer Res 2000, 60(15):4044-4048.

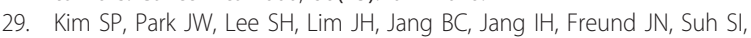
Mun KC, Song DK, et al: Homeodomain protein CDX2 regulates COX-2 expression in colorectal cancer. Biochem Biophys Res Commun 2004, 315(1):93-99

30. Cressey R, Pimpa S, Tontrong W, Watananupong O, Leartprasertsuke N: Expression of cyclooxygenase-2 in colorectal adenocarcinoma is associated with p53 accumulation and hdm2 overexpression. Cancer Lett 2006, 233(2):232-239.

31. Denkert C, Koch I, von Keyserlingk N, Noske A, Niesporek S, Dietel M, Weichert W: Expression of the ELAV-like protein HuR in human colon cancer: association with tumor stage and cyclooxygenase-2. Mod Pathol 2006, 19(9):1261-1269.
32. Lin DW, Nelson PS: The role of cyclooxygenase-2 inhibition for the prevention and treatment of prostate carcinoma. Clin Prostate Cancer 2003, 2(2):119-126

33. Duque J, Diaz-Munoz MD, Fresno M, Iniguez MA: Up-regulation of cyclooxygenase-2 by interleukin-1 beta in colon carcinoma cells. Cell Signal 2006, 18(8):1262-1269.

34. Maihofner C, Charalambous MP, Bhambra U, Lightfoot T, Geisslinger G, Gooderham NJ: Expression of cyclooxygenase-2 parallels expression of interleukin-1 beta, interleukin- 6 and NF-kappaB in human colorectal cancer. Carcinogenesis 2003, 24(4):665-671.

35. Gauthier ML, Pickering CR, Miller CJ, Fordyce CA, Chew KL, Berman HK, Tlsty TD: p38 regulates cyclooxygenase-2 in human mammary epithelial cells and is activated in premalignant tissue. Cancer Res 2005, 65(5):1792-1799.

Pre-publication history

The pre-publication history for this paper can be accessed here: http://www.biomedcentral.com/1471-2407/11/238/prepub

\section{doi:10.1186/1471-2407-11-238}

Cite this article as: Asting et al:: COX-2 gene expression in colon cancer tissue related to regulating factors and promoter methylation status. BMC Cancer 2011 11:238

\section{Submit your next manuscript to BioMed Central and take full advantage of:}

- Convenient online submission

- Thorough peer review

- No space constraints or color figure charges

- Immediate publication on acceptance

- Inclusion in PubMed, CAS, Scopus and Google Scholar

- Research which is freely available for redistribution

Submit your manuscript at www.biomedcentral.com/submit
C Biomed Central 